DR GILES DODSON is a lecturer in communication studies at Unitec, Auckland.

\section{A rich profile of protest and global} communication

Transnational Protests and the Media, edited by Simon Cottle and Libby Lester. New York: Peter Lang, 2011331 pp. ISBN 978-433109-85-0

$\mathrm{O}$ N 15 February 2003, several millions of engaged, networked and technologically enabled protesters took to the streets of world capitals to demand the halt of US-UK plans to invade Iraq. This broad coalition of opposition, which transcended the persistent localising imperatives of specific issues, identities, affiliations and interests, was global in scope and expressed clearly the 'imagined solidarity' or 'global civil society' of which it is the aspiration of transnational protest to mobilise.

Notably too, as Transnational Protests and the Media points out, in the pre-invasion phase of the Iraq

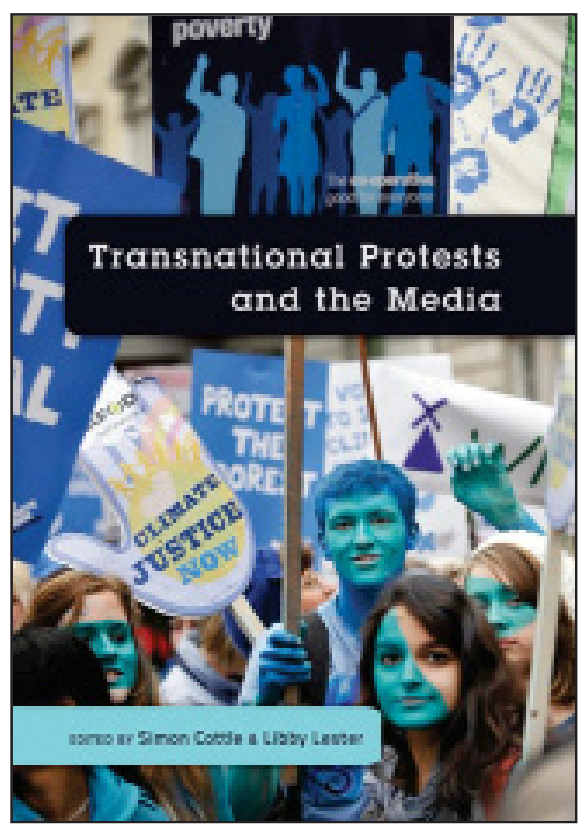

conflict, (UK) mass media undid the trend toward the marginalising and de-legitimising coverage of protest, providing 'generous and sympathetic reporting' of the million-strong rally (p. 70).

Nonetheless, as The Guardian reported the same day, for officials of the UK government, the largest public demonstrations ever seen, ' $\ldots$ changes nothing at all. The quicker it is done the better.' (The Guardian, 17 February, 2003). How then do scholars account for the 'democratising promise' of transnational protests and the ignoring responses of governments and international governmental organisations? 
This question is central to understanding contemporary protests and their role in the putative processes of emerging global solidarities and in the political processes of policy development. The point of protest on the world stage, after all, is to change it.

Transnational Protests and the Media provides a thoroughgoing account of the processes through and by which the 'transnational', as both identity and political action, is materialised through communicative activities. As such the volume provides insight into the transaction of global demonstrations through the formations of worldwide media and communication networks, attempting, and succeeding for the most part, in making sense of the vast and eclectic range of material thrown up by the international protest movements of the last decade.

However, while the authors suggest that the global era opens up possibilities to reconfigure communicative power, protest and thus politics, the failure of protest to bring about substantial political change in liberal democracies, is insufficiently investigated or theorised. The 'war on terror', global climate change and international financial crisis have all drawn significant global protest, yet substantial change in policy direction is difficult to discern internationally, to say nothing of the urgent, yet unsuccessful struggles against authoritarianism with which the volume engages (China, Iran).

Transnational Protests and the Media avoids approaching the power of protest and demonstration as determined by the capability provided by media technology. While today's communications ecology does indeed offer unprecedented opportunities to activists and enables the relocation of protest from the local to the global level-this book makes clear that how such technology is used and the extent of its efficacy must be carefully considered, both empirically and theoretically.

Although the translation of political protest into concrete policy direction is somewhat under-theorised in this volume, the book includes a host of chapters drawing on empirical analysis of the enactment and diffusion of mediated protest. And these empirical chapters are arranged according to the focus of the protest activities under examination; war and peace, economy and trade, ecology and climate, and civil and human rights.

In chapter four, Murray et al (2011) provide an analysis of the coverage of the anti-Iraq War protests by British media. Finding that the media provided favourable coverage of the mass demonstrations, the authors argue against the interpretation 
of the mass media's role as substantially supportive of the political elites and de-legitimatising of 'alternative' views.

The reversion, however, to media frames of patriotism and 'support the troops' once the invasion was underway, indicates how short-lived the contemporary media's sympathy towards the 'protest paradigm' may be.

In chapter five, Stephen Reese argues the Iraq protests must be understood in relation to the 'global news sphere', which has disrupted, to an extent, the tendency for dissent and protest to become marginalised by a media sector beholden to political and military elites. The argument however that the diffuse nature of the current media environment restricts the dismissal of public sentiment and that public opposition to war policy had 'serious political fallout' (p. 76), requires further development. On one hand, the pro-war leaders of the US and UK were returned to office, while on the other hand the election loss by the pro-war Spanish Prime Minister, Jose Maria Aznar, seems minor fallout when viewed globally.

Transnational protest is circumspect about attributing significant power to the international protest movement - in a clear-eyed chapter on the 'global social justice' movement and its efficacy post-Seattle, Rojecki (p. 92) argues that although in the contemporary era protesters are not constrained by the discursive limits imposed by elites (Gitlin, 1980), it remains uncertain that hardedged critique and reform can be launched from post-modern lifestyle and identity politics of which much of the 'global social justice' coalitions consist. Although new media technologies offer international demonstrators much-enhanced networking and publicity capabilities, Rojecki notes that despite the high profile of international demonstrations, the general level of political engagement among Western public's remains low and indeed the 'mainstream media' remain vitally important to protest, despite the establishment of worldwide independent (Indy) media centers and the like.

How transnational protest uses digital media for its own ends is vividly described in chapters 11 and 13 , focusing on the online campaigns to protect Tasmania's wilderness areas and on the exploits of the Sea Shepard conservation group respectively. A sophisticated understanding of the capacity for communications technology to project protests, treebased sit-in and the violence of prologging groups enabled Tasmanian environmental groups to over come their relative obscurity and globalpowerlessness to establish substantial international networks and media 
coverage, frequently garnering supportive coverage in mainstream media.

Sea Shepard, as local readers will be very aware have taken their use, manipulation and exploitation of the media substantially further, in their campaigns to halt Japanese whaling in the 'global commons' of the Southern Ocean. Incorporating pop-cultural pirate-imagery with spectacular and daring encounters with the Japanese whaling fleet - and deluging media outlets, activist networks, YouTube and Twitter with their self-produced reportage, Sea Shepard have successfully cultivated a 'global citizenship' and 'imagined solidarity' around the protection of Southern whales, only possible through digital and satellite communication and information technologies. Although 'image events' (DeLuca, 1999) are not novel within the protest repertoire, Crouch and Damjanov argue in chapter 13 that Sea Shepard's construction of a globally common, spectacular, transnational-scape constitutes a novel development. Furthermore, the spectacular nature of Sea Shepard's mediated activities confounds theorists such as Baudrillard and Debord, who dismiss the potential for progressive social action within the 'society of the spectacle'. As the authors point out, the spectacle of anti-whaling activist-pirates has been vigorously and successfully exploited by Sea Shepard as a galvanising political tool.

Transnational Protests and the Media provides a rich and nuanced view of the interconnection between global protest and global communication processes. While the question of the impotence of protest in liberal democracy is under-examined, the volume is commendably circumspect over the power of new media to deliver global profile, impact and efficacy to global protest. The relationship between protest, power and the global political-public sphere has however been altered by the contemporary configurations of transnational networks and an uneven and intermittent emergence of a global 'imagined solidarity' must be considered in its local particular context, a theme emphasised by several contributors to this volume.

Transnational Protests provides a clear account of many of these particularities and as such is a welcome and current contribution to the field of international communication.

\section{References}

DeLuca, K. M. (1999) Image Politics. New York: Guildford Press

Gitlin, T. (1980). The whole world is watching. Berkeley: University of California Press. 